\title{
BY-LAWS OF THE AMERICAN MATHEMATICAL SOCIETY
}

\author{
ARTICLE I
}

Officers

Section 1. There shall be a President, a President Elect (during the even-numbered years only), an Ex-president (during the odd-numbered years only), three Vice Presidents, a Secretary, four Associate Secretaries, and a Treasurer.

Section 2. It shall be a duty of the President to deliver an address before the Society at the close of his term of office or within one year thereafter.

\section{ARTICLE II}

\section{Board of Trustees}

Section 1. There shall be a Board of Trustees consisting of seven trustees, five trustees elected by the Society in accordance with Article VII, together with the President and Treasurer of the Society ex officio. The Board of Trustees shall designate its own presiding officer and secretary.

Section 2. The function of the Board of Trustees shall be to receive and administer the funds of the Society, to have full legal control of its investments and properties, to make contracts and, in general, to conduct all business affairs of the Society.

Section 3. The Board of Trustees shall have the power to appoint such assistants and agents as may be necessary or convenient to facilitate the conduct of the affairs of the Society, and to fix the terms and conditions of their employment. The Board may delegate to the officers of the Society duties and powers normally inhering in their respective corporative offices, subject to supervision by the Board. The Board of Trustees may appoint committees to facilitate the conduct of the financial business of the Society and delegate to such committees such powers as may be necessary or convenient for the proper exercise of those powers. Agents appointed, or members of committees designated, by the Board of Trustees need not be members of the Board.

Nothing herein contained shall be construed to empower the Board of Trustees to divest itself of responsibility for, or legal control of, the investments, properties and contracts of the Society.

\section{ARTICLE III}

\section{Publications Committees}

Section 1. There shall be nine Publications Committees, which shall be the eight Editorial Committees specified in Section 2 of this Article and the Committee on Printing and Publishing specified in Section 3 of this Article.

Section 2. There shall be eight Editorial Committees as follows: committees for the Bulletin, for the Proceedings, for the Colloquium Publications, for Mathematical Surveys, for Mathematical Reviews, a joint committee for the Transactions and the Memoirs, a committee consisting of the representatives of the Society on the Board of Editors of the American Journal of Mathematics, and a committee for Mathematics of Computation.

Section 3. There shall be a Committee on Printing and Publishing.

Section 4. The size of each Publication Committee shall be determined by the Council. 


\section{ARTICLE IV}

\section{Council}

Section 1. The Council shall consist of fifteen members at large and the following ex officio members: the officers of the Society specified in Article I, the members of the Publications Committees specified in Article III, any former Secretary for a period of two years following his terms of office, and members of the Executive Committee who remain on the Council by the operation of Article VII, Section 4.

Section 2. The Council shall formulate and administer the scientific policies of the Society and shall act in an advisory capacity to the Board of Trustees.

Section 3. In the absence of the Secretary from any meeting of the Council, one of the Associate Secretaries present may be designated as Acting Secretary for the meeting, either by written authorization of the Secretary, or, failing that, by majority agreement among the Associate Secretaries present.

Section 4. All members of the Council shall be voting members. The method for settling matters before the Council at any meeting shall be by majority vote of the members present. If the result of a vote is challenged, it shall be the duty of the presiding officer to determine the true vote by a roll call. In a roll call vote, each Council member shall vote only once (although he may be a member of the Council in several capacities), and he shall state before the vote in which capacity he votes. The group consisting of the four Associate Secretaries shall have one vote, and it shall be divided equally among those who vote as Associate Secretaries. Each of the nine Publications Committees shall have one vote, and it shall be divided equally among those who vote as members of the respective Publications Committees. All other members of the Council shall have one vote each. Fractional votes shall be counted.

Section 5. Any group of members of the Council who have a total of five votes as defined in Section 4 of this Article shall constitute a quorum for the transaction of business at any meeting of the Council.

Section 6. Between meetings of the Council, business may be transacted by a mail vote. Votes shall be counted as in the case of a roll call vote as specified in Section 4 of this Article, "members present" being replaced by "members voting." An affirmative vote by mail on any proposal shall be declared if and only if (a) more than half of the total number of possible votes is received by the time announced for the closing of the polls, and (b) at least three-quarters of the votes received by then are affirmative. If members who have a total of five or more votes request postponement at the time of voting, action on the matter at issue shall be postponed until the next meeting of the Council, unless either (1) at the discretion of the Secretary, the question is made the subject of a second vote by mail, in connection with which brief statements of reason, for and against, are circulated or (2) the Council places the matter at issue before the Executive Committee for action.

Section 7. The Council may delegate to the Executive Committee (Article V) certain of its duties and powers. Between meetings of the Council the Executive Committee shall act for the Council on such matters and in such ways as the Council may specify. Nothing herein contained shall be construed as empowering the Council to divest itself of responsibility for formulating and administering the scientific policies of the Society.

Section 8. The Council shall also have power to speak in the name of the Society with respect to matters affecting the status of mathematics or mathematicians, such as proposed or enacted Federal or State Legislation, conditions of employment in universities, colleges, or business, research or industrial organizations, regulations, 
policies or acts of governmental agencies or instrumentalities, and other items which tend to affect the dignity and effective position of mathematics.

With the exception noted in the next paragraph, a favorable vote of two-thirds of the entire membership of the Council, taken in accordance with the provisions of Section 4 of this Article, shall be necessary to authorize any statement in the name of the Society with respect to such matters. With the exception noted in the next paragraph, such a vote may be taken only if written notice shall have been given to the Secretary by the proposer of any such resolution not later than one month prior to the Council meeting at which the matter is to be presented, and the vote shall be taken not earlier than one month after the resolution has been discussed by the Council.

If, at a meeting of the Council, there are present members having a total of twelve votes, as defined in Section 4 of this Article, then the prior notification to the Secretary may be waived by unanimous consent. In such a case, a unanimous favorable vote by those present shall empower the Council to speak in the name of the Society.

The Council may also refer the matter to a referendum mail vote of the entire membership of the Society, and shall make such reference if a referendum is requested, prior to final action by the Council, by two hundred or more members. The taking of a referendum shall act as a stay upon Council action until the votes have been canvassed, and thereafter no action may be taken by the Council except in accordance with a plurality of the votes cast in the referendum.

\section{ARTICLE V \\ Executive Committee}

Section 1. There shall be an Executive Committee of the Council, consisting of four elected members and the following ex officio members: the President, the Secretary, the President Elect (during even-numbered years), and the Ex-president (during odd-numbered years).

Section 2. The Executive Committee of the Council shall be empowered to act for the Council on matters which have been delegated to the Executive Committee by the Council. If three members of the Executive Committee request that any matter be referred to the Council, the matter shall be so referred. The Executive Committee shall be responsible to the Council and shall report its actions to the Council. It may consider the agenda for meetings of the Council and may make recommendations to the Council.

Section 3. Each member of the Executive Committee shall have one vote. An affirmative vote on any proposal before the Executive Committee shall be declared if and only if at least four affirmative votes are cast for the proposal. A vote on any proposal may be determined at a meeting of the Executive Committee, but it shall not be necessary to hold a meeting to determine a vote.

\section{ARTICLE VI}

\section{Executive Director}

Section 1. There shall be an Executive Director who shall be a paid employee of the Society. He shall have charge of the central office of the Society, and he shall be responsible for the general administration of the affairs of the Society in accordance with the policies that are set by the Board of Trustees and by the Council.

Section 2. The Executive Director shall be appointed by the Board of Trustees with the consent of the Council. The terms and conditions of his employment shall be fixed by the Board of Trustees. 
Section 3. The Executive Director shall work under the immediate direction of a committee consisting of the President, the Secretary, and the Treasurer, of which the President shall be chairman ex officio. The Executive Director shall attend meetings of the Board of Trustees, of the Council, and of the Executive Committee, but he shall not be a member of any of these bodies.

\section{ARTICLE VII}

\section{Election and Terms of Officers}

Section 1. The term of office shall be one year in the case of the President Elect and the Ex-president, five years in the case of the Trustees, two years in the case of the President, Vice Presidents, the Secretary, the Associate Secretaries and the Treasurer. The term of office in case of members of the Publications Committees shall be four years for the Proceedings and Transactions (except for the years 1967 through 1970 ) and three years for the remaining committees, except that when the size of a Publication Committee is changed the Council may authorize the election of a member for a shorter term. The term of office for members at large of the Council shall be three years, five of the members at large retiring annually. The term of office for elected members of the Executive Committee shall be two years, two of the elected members retiring annually. All terms of office shall begin on January 1 and terminate on December 31 with the exception that the officials specified in Articles I, II, III, IV, and V (excepting the President Elect and Ex-president) shall continue to serve until their successors have been duly elected and qualified.

Section 1a. For the years 1967 through 1970, the terms of members of the Editorial Committees of the Transactions and Proceedings shall be as follows:

Transactions:

R. S. Palais

Frank Peterson

David Buchsbaum

H. P. McKean, Jr.

Proceedings:

R. C. Buck

A. P. Mattuck

Irving Reiner

W. R. Wasow
Term Expires December 31

1969

1969

1970

1970

Term Expires December 31

1968

1969

1969

1970

On January 1, 1971, this section, as well as the parenthetical phrase "(except for the years 1967 through 1970)" of Section 1 will be repealed.

Section 2. The President Elect, the Vice Presidents, the Secretary, the Associate Secretaries, the Treasurer, the Trustees, the members of the Publications Committees, and the members-at-large of the Council shall be elected by written ballot. An official ballot shall be sent to each member of the Society by the Secretary on or before October 10, and such ballots, if returned to the Secretary in envelopes bearing the name of the voter and received within 30 days, shall be counted. Each ballot shall contain one or more names proposed by the Council for each office to be filled, with blank spaces in which the voter may substitute other names. A plurality of all votes cast shall be necessary for election. In case of failure to secure a plurality for any office, the Council shall choose by written ballot among the members having the highest number of votes.

Section 3. At the end of his term of office, the President Elect shall become the 
President. At the end of his term of office, the President shall become the Expresident.

Section 4. On or before January 15 , the Secretary shall send to all members of the Council for a mail vote a ballot containing two names for each place to be filled on the Executive Committee. The nominees shall be chosen by a committee appointed by the President. Members of the Council may vote for persons not nominated. Any member of the Council who is not an ex officio member of the Executive Committee (see Article V, Section 1) shall be eligible for election to the Executive Committee. In case a member is elected to the Executive Committee for a term extending beyond his regular term on the Council, he shall automatically continue as a member of the Council during his term on the Executive Committee.

Section 5. The President and Vice Presidents shall not be eligible for immediate re-election to their respective offices. A member-at-large or an ex officio member of the Council shall not be eligible for immediate election (or re-election) as a member-atlarge of the Council.

Section 6. If the President of the Society die or resign while a President Elect is in office, the President Elect shall serve as President for the remainder of the year and thereafter shall serve his regular two-year term. If the President of the Society die or resign when no President Elect is in office, the Council, with the approval of the Board of Trustees, shall designate one of the Vice Presidents to serve as President for the balance of the regular presidential term. If the President Elect of the Society die or resign before becoming President, his office shall remain vacant until the next regular election of a President Elect, and the Society shall, at the next Annual Meeting, elect a president for a two-year term. If the Ex-president die or resign before expiration of his term of office, the Council, with the approval of the Board of Trustees, shall designate a former President of the Society to serve as Ex-president during the remainder of the regular term of the Ex-presidency. Such vacancies as may occur at any time in the group consisting of the Vice Presidents, the Secretary, the Associate Secretaries, the Treasurer, and the Members of the Publications Committees shall be filled by the Council with the approval of the Board of Trustees. If a member of a Publications Committee takes temporary leave from his duties, that Committee shall nominate a substitute for consideration by the Council. The Council shall then elect a substitute. The Council shall fill from its own membership any vacancy in the elected membership of the Executive Committee.

Section 7. If any Trustee die or resign during his tenure of office, the vacancy thus created shall be filled for his unexpired term by the Board of Trustees.

Section 8. If any member at large of the Council die or resign more than one year before the expiration of his term, the vacancy for the unexpired term shall be filled by the Society at the next Annual Meeting.

Section 9. In case any officer die or decline to serve between the time of election and the time at which he was to assume office, the vacancy shall be filled in the same manner as if he had served one day of his term.

\section{ARTICLE VIII}

\section{Members and Their Election}

Section 1. Election of members shall be by vote of the Council or of its Executive Committee.

Section 2. There shall be four classes of members, namely ordinary, contributing, corporate, and institutional.

Section 3. Application for admission to ordinary membership shall be made by 
the applicant on a blank provided by the Secretary, and shall be approved either by two ordinary members of the Society or by the institutional member whose nominee he is (see Article IX, Section 6). Such applications shall not be acted upon until at least thirty days after their presentation to the Council (at a meeting or by mail), except in the case of members of other societies entering under special action of the Council approved by the Board of Trustees.

Section 4. An ordinary member may become a contributing member by paying the dues for such membership. (See Article IX, Section 3.)

Section 5. A university or college, or a firm, corporation, or association interested in the support of mathematics may be elected a corporate or an institutional member.

\section{ARTICLE IX}

\section{Dues and Privileges of Members}

Section 1. Any applicant shall be admitted to ordinary membership immediately upon election by the Council (Article VIII) and the discharge within sixty days of election of his first annual dues. Dues may be discharged by payment or by remission when the provision of Section 7 of this Article is applicable. The first annual dues shall apply to the year of election, except that if any applicant is elected after August 15 of any year he may elect to have his first annual dues apply to the following year.

Section 2. The annual dues of an ordinary member of the Society shall be established by the Council with the approval of the Trustees. The Council with the approval of the Trustees may establish special rates in exceptional cases and for members of an organization with which the Society has a reciprocity agreement.

Section 3. The minimum dues for a contributing member shall be three halves of the dues of an ordinary member per year. Members may, upon their own initiative, pay larger dues.

Section 4. The minimum dues of an institutional member shall depend on the amount of published material credited to that member in certain journals during a specific period. The formula for computing these dues shall be established from time to time by the Council subject to approval by the Board of Trustees. Institutions may pay larger dues than the computed minimum.

Section 5 . The minimum annual dues of a corporate member shall be one thousand dollars.

Section 6. The privileges of a corporate or an institutional member shall depend on its dues in a manner to be determined by the Council, subject to approval by the Board of Trustees. These privileges shall be in terms of Society publications to be received by the institution and of the number of persons it may nominate for ordinary membership in the Society.

Section 7. The dues of an ordinary member of the Society shall be remitted for any years during which he is the nominee of an institutional member.

Section 8. After retirement from active service on account of age, any ordinary or contributing member who is not in arrears of dues and with membership extending over at least twenty years may, by giving proper notification to the Secretary, have his dues remitted, on the understanding that he will thereafter receive the Notices but not the Bulletin.

Section 9. An ordinary or contributing member shall receive the Notices and Bulletin as privileges of membership during each year for which his dues have been discharged.

Section 10. The annual dues of ordinary, contributing, and corporate members shall be due by January first of the year to which they apply. The Society shall submit 
bills for dues. If the annual dues of any member remain undischarged beyond what the Board of Trustees deem to be a reasonable time, his name shall, after due notice, be removed from the list of members. If a member wishes to discontinue his membership at any time, he shall submit his resignation in writing to the Society.

Section 11. Any member who became a life member before October 25, 1941, by the payment of a sum determined in accordance with actuarial principles shall have for life the status and privileges of an ordinary member without further payment of dues. No additional applications for life memberships will be accepted.

\section{ARTICLE X}

\section{Meetings}

Section 1. The Annual Meeting of the Society shall be held between the fifteenth of December and the tenth of February next following. Notice of the time and place of this meeting shall be mailed by the Secretary or an Associate Secretary to the last known post office address of each member of the Society. The times and places of the Annual and other meetings of the Society shall be designated by the Council. There shall be a business meeting of the Society at the Annual Meeting and at the Summer Meeting. A business meeting of the Society shall take final action only on business accepted by unanimous consent, or business notified to the full membership of the Society in the call for the meeting. Such notification shall be made only when so directed by a previous business meeting of the Society or by the Council.

Section 2. Meetings of the Executive Committee may be called by the President; he shall call a meeting at any time upon the written request of two of its members.

Section 3. The Council shall meet at the Annual Meeting of the Society. Special meetings of the Council may be called by the President; he shall call a special meeting at any time upon the written request of five of its members. No special meeting of the Council shall be held unless written notice of it shall have been sent to all members of the Council at least ten days before the day set for the meeting.

Section 4. The Board of Trustees shall hold at least one meeting in each calendar year. Meetings of the Board of Trustees may be called by the President, the Treasurer, or the Secretary of the Society upon three days' notice of such meetings mailed to the last known post office address of each Trustee. The Secretary of the Society shall call a meeting upon the receipt of a written request of two of the Trustees. Meetings may also be held by common consent of all the Trustees.

Section 5. Papers intended for presentation at any meeting of the Society shall be passed upon in advance by a program committee appointed by or under the authority of the Council; and only such papers shall be presented as shall have been approved by such committee. Papers in form unsuitable for publication, if accepted for presentation, shall be referred to on the program as preliminary communications or reports.

\section{ARTICLE XI}

\section{Publications}

Section 1. The Society shall publish an official organ called the Bulletin of the American Mathematical Society. It shall publish three journals, known as the Transactions of the American Mathematical Society, the Proceedings of the American Mathematical Society and Mathematics of Computation. It shall publish a series of mathematical papers known as the Memoirs of the American Mathematical Society. The object of the Transactions, Proceedings, Memoirs and the Mathematics of Computation is to make known important mathematical researches. It shall publish a periedical called 
Mathematical Reviews, containing abstracts or reviews of current mathematical literature. It shall publish a series of volumes called Colloquium Publications which shall embody in book form new mathematical developments. It shall publish a series of monographs called Mathematical Surveys which shall furnish expositions of the principal methods and results of particular fields of mathematical research. It shall also cooperate in the conduct of the American Journal of Mathematics. It shall publish a news periodical known as the Notices of the American Mathematical Society, containing programs of meetings, items of news of particular interest to mathematicians, and such other materials as the council may direct.

Section 2. The editorial management of the publications of the Society listed in Section 1 of this article, with the exception of the Notices, and the participation of the Society in the editorial management of the American Journal of Mathematics shall be in charge of the respective Editorial Committees as provided in Article III, Section 2. The editorial management of the Notices shall be in the hands of a committee consisting of the Executive Director and the Secretary.

Section 3. The Committee on Printing and Publishing shall advise the Council and Board of Trustees on business and noneditorial matters concerning the publications of the Society, and shall perform such other functions and shall exercise such powers as are properly assigned or delegated to it by the Council or the Board of Trustees.

\section{ARTICLE XII}

\section{Amendments}

These By-Laws may be amended or suspended at any meeting of the Society on recommendation of the Council and by a two-thirds vote of the members present, provided notice of such proposed action and of its general nature shall have been given in the call for such meeting. 